\title{
ARTICLE
}

\section{Towards a more just insanity defence: recovering moral wrongfulness in the M'Naghten Rules}

\author{
Keith J. B. Rix
}

Keith Rix is Honorary Consultant Forensic Psychiatrist, Norfolk and Suffolk NHS Foundation Trust, and Visiting Professor of Medical Jurisprudence, University of Chester, where he is involved with its MSc in Medicolegal Practice. He is an elected Honorary Fellow of the Faculty of Forensic and Legal Medicine of the Royal College of Physicians. Correspondence Professor Keith J. B. Rix, Institute of Medicine, Bache Hall, Chester CH2 1JR, UK Email: keith@drkeithrix.co.uk a. M'Naghten is the customary spelling in law reports, but of all possible spellings it is probably the least correct (Diamond 1977). Original research by Moran (1981), including discovery of a hitherto unknown second signature of McNaughtan and several signature of his father, provides convincing evidence that the correct spelling is McNaughtan. In this article the form 'M'Naghten' is used when referring to the Rules, in conformity with the convention in law reports, and 'McNaughtan' when referring to the person.

\section{SUMMARY}

This article describes how the M'Naghten Rules, which govern the law of insanity in England and Wales, came into existence. In relation to knowledge of the wrongfulness of the alleged act, the article reveals how the Court of Appeal has sought to limit the defence, whereas the courts of first instance, and a number of other jurisdictions, have adopted interpretations of the Rules that accord more closely with the law of insanity as it existed at the time of Daniel McNaughtan's trial and that the Rules were probably meant to formulate. Three cases are used to illustrate the difficulties resulting from the position adopted by the Court of Appeal. It is suggested that in cases where the insanity defence is raised, justice is likely to be better served by addressing specifically and separately the accused's understanding or appreciation of the moral wrongfulness of the alleged act and their knowledge as to whether the alleged act is contrary to the law of the land.

\section{LEARNING OBJECTIVES}

- Understand the way in which the Court of Appeal in England and Wales has limited the application of the insanity defence and how other UK jurisdictions have included knowledge of moral wrongfulness in their insanity defences

- Know what questions should be asked in cases where the insanity defence is raised, so as to reduce the likelihood of injustice

- Understand how more focused psychiatric opinions, in cases where the insanity defence is raised, may assist the appellate courts in England and Wales in recovering moral wrongfulness as part of the test of insanity

\section{DECLARATION OF INTEREST}

None

On Friday 3 March 1843 Daniel McNaughtan ${ }^{2}$ stood trial at London's Central Criminal Court for the 'wilful murder' of Edward Drummond, private secretary to the Prime Minister, Sir Robert Peel. The day was taken up by the opening speech for the Crown. On Saturday 4 March, proceedings began with the speech for the defence. By the end of what must have been another long day McNaughtan had been found not guilty on the ground of insanity.

Reaction was immediate and intense. The next morning, Sunday 5 March, Sir Robert Peel lamentably informed Queen Victoria of the verdict (Benson 1908). An angry letter appeared in The Times on Monday 6 March written by someone, under the pseudonym Justus, complaining about McNaughtan being 'not the only dangerous lunatic at large' and asking whether the law was 'sufficient for the protection of the public' (Justus 1843). It was accompanied by some satirical verses (Box 1) which, like the letter, but for the quaintness of the language, could have been penned by one of today's tabloid journalists seeking to increase public fear of the mentally disordered.

The very same day in the House of Lords, Lord Brougham, referring to 'the emergency of the case', opened a debate on 'insanity and crime' (Hansard 1843a). The Lord Chancellor indicated that he had already given this matter some attention 'with a view to discovering if anything could be done to remedy this evil'. He said that he was about to communicate with those who were best placed to inform him, the judges of the Court of Common Pleas.

On 12 March Queen Victoria wrote to Sir Robert Peel expressing her concern in the following

BOX 1 'On a late acquittal'

'Ye people of England exult and be glad For ye're now at the will of the merciless mad. Why say ye that but three authorities reign Crown, Commons and Lords? - You omit the insane. They're a privileged class whom no statute controls, And their murderous charter exists in their souls. Do they wish to spill blood - they have only to play A few pranks - get asylum'd a month and a day Then Heigh! to escape from the mad doctor's keys And to pistol or stab whomsoever they please.'

(Justus 1843) 
terms: 'The law may be perfect, but how is it that whenever a case for its application arises, it proves of no avail?' (Benson 1908).

Debate resumed in the House on 13 March (Hansard 1843b) and was opened by the Lord Chancellor, who referred to the 'deep feeling in the public mind' that had been created by the trial at the end of which McNaughtan had 'escaped with impunity'. The debate was adjourned in order that the judges could be summoned for their opinion using a piece of constitutional machinery that allowed the House to seek assistance by putting to judges abstract questions of existing law.

On 19 June they delivered their answers (M'Naghten's Case (1843)). There were 12 judges. One, Mr Justice Maule, dissented from the majority. Lord Tindal, the Chief Justice, who had presided over McNaughtan's trial, delivered the answers of the majority. Two of the questions related to the direction to the jury in insanity cases. The answers to these questions have become known as the M'Naghten Rules ('the Rules') (Box 2).

\section{The Rules in operation}

To raise a successful defence under the Rules, it has to be proved that:

(a) the accused was labouring under a defect of reasoning

(b) the defect arose from a disease of the mind, and

(c) as a consequence of the defect of reasoning the accused either:

(i) did not know the nature and quality of the act he or she was doing, or

(ii) did not know that what he or she was doing was wrong.

The parts of the 'test' that relate to the consequences of the defect of reasoning have become known as the 'nature and quality' limb and the 'wrongfulness' (or 'wrongness') limb.

BOX 2 Direction to the jury in insanity cases

'To establish a defence on the ground of insanity it must be clearly proved that, at the time of committing the act, the party accused was labouring under such a defect of reason from disease of the mind, as not to know the nature and quality of the act he was doing, or if he did know it, that he did not know that what he was doing was wrong.

If the accused was conscious that the act was one which he ought not to do, and if that act was at the same time contrary to the law of the land, he is punishable.'

(M'Naghten's Case (1843))
There are difficulties that result from the seemingly narrowly cognitive scope of the defence. They arise from both the 'defect of reasoning' component and the 'knowledge' ('did not know') elements. This article is concerned principally with the difficulties that have resulted from the judicial interpretation of the wrongfulness limb, but it includes some consideration of the knowledge element.

It will be argued that the appellate courts have erroneously restricted the meaning of 'wrong' to legal wrongness and thereby they have limited the application of the defence in a way that was probably not intended and that deprives of the defence many mentally disordered persons who, but for the effects of their mental disorder on their behaviour, would not otherwise be 'criminalised'. This restriction has been recognised by the Law Commission (2013: p. 11) in its observation that 'English law has adopted an unusually, and arguably unjustifiably, narrow interpretation of the "wrongfulness" limb'.

\section{Judicial interpretation of the Rules by the higher courts in England and Wales}

Over the course of 170 years the appellate courts of England and Wales have grappled with the meaning of wrongfulness in the Rules on only three occasions.

The first case to reach the Court of Appeal was the First World War case of a Canadian infantry officer Georges Codère ( $R$ v Codère (1917)) (Box 3). The grounds for appeal were based on both limbs. In relation to the 'nature and quality' limb it was argued that 'nature' refers to the physical aspect of the act and 'quality' to its moral aspect. It was argued that 'wrong' in the 'wrongfulness' limb included moral as well as legal wrongfulness. Neither argument was accepted. The Court of Appeal held that 'in using the language "nature and quality" the judges were only dealing with the physical character of the act and were not intending to distinguish between physical and moral aspects of the act'. The Court also rejected the submission that 'wrong' could mean 'an act which he ought not to do', as distinct from an act 'punishable by or contrary to law', stating 'The question of the distinction between morally and legally wrong opens wide doors'.

It was more than 30 years before the Court of Appeal again addressed the issue. This was in the case of $R{ }_{V}$ Windle [1952]. Mr Windle's wife had been threatening suicide. Mr Windle administered a fatal dose of 100 aspirin to her and when he was arrested he commented, 'I suppose I'll hang for this'. He was convicted of murder and 


\section{B0X 3 The case of Lieutenant Georges Codère}

Lieutenant Codère's regiment, the 41 st Regiment of Canadian Infantry, was already quartered at Bramshot on the Isle of Wight when Sergeant Ozanne arrived with the 9th Canadian Mounted Rifles. Codère offered to negotiate the exchange of Canadian dollars into sterling and received from Ozanne about $\$ 1500$ in Canadian money. Codère then offered money to a fellow officer if he would help him kill a man. Codère was known in his regiment as 'Fou Codère' and the officer told him to stop fooling. Codère went on to change the Canadian money for $£ 282$ and offered another sergeant of the same regiment $£ 50$ if he would 'make a man disappear' by hitting him over the head with a cravache (an officer's weighted trench stick). The sergeant, believing that he was humouring a lunatic, suggested poison instead. Although Codère may have attempted to poison Ozanne by putting some white substance in his whiskey, he was found dead with his head smashed, his throat cut nearly to the spine and 45 cuts inflicted to his face. Codère tried to put the blame on a servant and wrote to him telling him to confess.

There was evidence that Codère was 'quite abnormal mentally, and was not regarded as being responsible for his actions; that he could not carry on a sustained conversation' His major said that he had never intended to take Codère to France as 'he was unable to handle men from the moral or mental point of view'. Evidence was given that at dinner with fellow officers following the killing and when subsequently talking to the sergeant who advised as to the poison, and to whom he admitted the killing, Codère showed no emotion. There was evidence that his paternal aunt had been insane, as had several maternal cousins. He was reported to have been sent away from an agricultural college in Canada because he was thought not to be 'compos mentis'. Dr Stoddart interviewed Codère three times, found him boastful and subject to delusions and concluded that he was not of sound mind. Dr Craig, who saw Codère for the prosecution, said that, although he would not class him as absolutely normal, he thought that he knew the difference between right and wrong and could not be certified insane.

On 5 February 1916 Codère was convicted of murder and sentenced to death. On appeal it was argued that the trial judge failed to explain to the jury that 'wrong' in the M'Naghten Rules did not mean just 'punishable or contrary to law', but could also mean 'an act which he ought not to do' and that 'quality' in 'nature and quality' referred to the moral aspect of the act. It was submitted that the judge should have told the jury that the question was, 'Did the accused know that the act was immoral?' The appeal was unsuccessful.

(Details and quotations from R v Codère (1917)) b. At the time, the Appellate Committee of the House of Lords 'the Law Lords' - was the highest appellate court for criminal cases in England and Wales. This function is now served by the Supreme Court. appealed against his conviction on the grounds that 'wrong' meant 'morally wrong'. Lord Chief Justice Goddard rejected this argument, stating that the test must be whether an act is contrary to law and expressing the opinion that 'there is no doubt that the word "wrong" in the McNaughton [sic] Rules means contrary to law, and does not have the same vague meaning which may vary according to the opinions of different persons as to whether a particular act might not be justified'. He continued, 'Courts of law can only distinguish between that which is in accordance with the law and that which is contrary to law', adding, 'The law cannot embark on the question, and it would be an unfortunate thing if it were left to juries to consider whether some act was morally right or wrong'. However, as shown below, this is just what juries do in other jurisdictions.

Many more decades passed again before the Court of Appeal addressed the issue in $R \mathrm{~V}$
Johnson [2007]. This was a non-fatal stabbing case. Mr Johnson had schizophrenia and believed that 'firewalls' were interfering with him. There was psychiatric evidence that this was the moral justification for the stabbing. However, it was agreed that he knew that this was legally wrong and the trial judge refused to allow the defence to go to the jury. Following conviction, Mr Johnson appealed and, as well as considering the ruling in the Windle case, the Court considered the observations of a number of legal commentators and 'the highly persuasive ruling' in the Australian case of Stapleton v R (1952) (see below), but nevertheless concluded, 'the strict position remains as stated in Windle'. Although the Court obviously recognised that there was an important issue here, and invited counsel to formulate a question or questions of public importance which the Court could certify so that the House of Lords ${ }^{b}$ could decide whether it wanted to revisit the Rules, leave to appeal was subsequently refused.

\section{Judicial application of the Rules by the courts of first instance in England and Wales}

Probably one of the reasons why the Court in Johnson attempted to pave the way for the issue to be addressed in the House of Lords was the observation of Lord Justice Latham that the courts of first instance had been prepared to approach the wrongfulness issue 'on a more relaxed basis'. The Court had been presented with evidence based on empirical research by Mackay and his colleagues (Mackay 1990, 1999, 2006).

The first study (Mackay 1990) was of 49 successful insanity defences in England and Wales between 1975 and 1978. Although there were 28 cases in which the wrongfulness limb was identified as the relevant basis of the defence, including 6 cases in which there was reliance on both limbs, it was observed that in many of these cases there seemed to have been little attempt to distinguish between lack of knowledge of legal and moral wrongfulness. Indeed, the situation was such that it was concluded that 'the general impression gained from reading the documentation in these cases was that the wrongness issue was being treated in a liberal fashion by all concerned, rather than in the strict manner regularly depicted by legal commentators'. Put another way, 'if psychiatrists do apply a different test from that which the law requires it will be either because they are ignorant of the law or because they are bending it' (Dr Alan Reed quoted in Law Commission (2013: p. 243)). Furthermore, there were 16 cases in which the successful limb could not be identified and in 11 of these the psychiatric reports were such that 'the 
Rules could be regarded as having been considered by implication' in that, for example, lack of intent attributable to mental illness and psychosis were identified as the basis of the defence.

Mackay et al then extended their analysis up to 2001 and studied the 100 psychiatric reports where reliance was on the wrongfulness limb (Mackay 2006). They found that 28 made some reference to knowledge of legal wrongness, 4 to both forms of wrongness and 68 to moral or unspecified wrongness.

If Mackay and his colleagues had carried out their research 100 years earlier, there is no reason to suppose that their findings would have been any different. When Ronald True appealed against his conviction for the murder of a prostitute it was submitted, albeit unsuccessfully, that study of a number of cases between 1881 and 1921 indicated that the Rules had been relaxed $(R \mathrm{~V}$ True (1922)). Although his appeal did not turn on the wrongfulness issue, it is of some significance that the first case on which True's counsel relied was $R$ v Davis (1881), where Mr Justice Stephen gave the following direction:

'As I understand the law, any disease which so disturbs the mind that you cannot think calmly and rationally of all the different reasons to which we refer in considering the rightness or wrongness of an action - any disease which so disturbs the mind that you cannot perform that duty with some moderate degree of calmness and reason may be fairly said to prevent a man from knowing that what he did was wrong.'

The significance is that Mr Justice Stephen was a distinguished Victorian jurist, indeed probably the most knowledgeable and informed authority on criminal law at the turn of the 19th century, and, as Sir James Fitzjames Stephen, was the author of a History of the Criminal Law of England, where he wrote:

"The word "wrong" is ambiguous [...]. It may mean either "illegal" or "morally wrong" for there may be such a thing as illegality not involving moral guilt.' (Stephen 1883).

If the Rules had been relaxed, it would appear that they were relaxed from the very beginning and not just from the 1880s. It is perhaps not surprising that Mr Justice Maule, who delivered the single dissenting judgment in M'Naghten's Case, should only a few months later direct a jury in the terms 'so insane that he did not know right from wrong' ( $R$ v Higginson (1843)). What is perhaps surprising is Lord Chief Justice Tindal's direction to a jury the following year in the terms 'no competent use of his understanding so as to know that he was doing a wrong thing' ( $R v$ Vaughan (1844)). As observed in Stapleton, 'Clearly enough their Lordships both considered the contrast to be between right and wrong in the general sense and not lawfulness and unlawfulness'. Lord Chief Justice Tindal's direction in Vaughan is less surprising when compared with his address to the jury at McNaughtan's trial. He referred to whether McNaughtan 'had that competent use of his understanding as that he knew that he was doing, by the very act itself, a wicked and a wrong thing' and was 'capable of distinguishing between right and wrong'. When Lord Chief Justice Tindal's answers to the House of Lords in M'Naghten's Case are viewed in the context of his directions to juries when sitting in a court of first instance, the distinction seems to be not so much between 'strict' and 'relaxed' application of the Rules as between 'theory', or abstract consideration, and 'practice'. Again as observed in Stapleton, 'The judges were not asked to improvise a rule but to formulate the rule that existed and that is all they purported to do' and what better evidence could there be of the existing rule than Lord Chief Justice Tindal's own application of it when sitting as a first instance judge.

Indeed, closer examination of the Rules indicates that the judges were well aware of the distinction between moral and legal wrongfulness. This distinction is clear when they refer to how an accused could be 'conscious that the act was one which he ought not to do, and if that act was at the same time contrary to the law of the land' (Box 2). The former must be referring to moral wrongfulness and the latter to legal wrongfulness.

\section{Evolution and abandonment abroad}

Not only is the Court of Appeal in England and Wales out of step with the courts of first instance, but it has become progressively out of step with other jurisdictions.

\section{Australia}

In Australia the test adopted in $R$ v Porter (1933) represents a similar approach to that of the courts of first instance in England and Wales, and in $R$ v Sodeman [1936] the High Court of Australia confirmed on appeal that 'wrong' meant 'morally wrong' (Box 4). The High Court went further in the appeal in Stapleton. It not only used the test in Porter as an example of the proper application of the existing law (which the Rules were meant to formulate and which law it summarised thus: 'What appears is that an incapacity to know the difference between good and evil was, if it was the outcome of mental disease, a test of irresponsibility'); it also said that it was 'not prepared to accept or act upon' the decision in Windle. 
B0X 4 Key Australian cases

$R v$ Porter (1933): 'The question is whether he was able to appreciate the wrongness of the particular act he was doing at the particular time. Could this man be said to know in this sense whether his act was wrong if [...] he could not think rationally of the reasons which to ordinary people make that act right or wrong? What is meant by "wrong"? [...] Wrong is wrong having regard to the everyday standards of reasonable people. [...] [T]he main question [...] is whether [...] the man whom you are trying $[\ldots]$ was disabled from knowing that it was a wrong act to commit in the sense that a body of reasonable men understand right and wrong and that he was disabled from considering with some degree of composure and reason what he was doing and its wrongness.'

$R v$ Sodeman [1936]: 'In general it may be correctly said that, if the disease or mental derangement so governs the faculties that it is impossible for the party accused to reason with some degree of calmness in relation to the moral quality of what he is doing, he is prevented from knowing that what he does is wrong.'

Porter also develops what is meant by the word 'know' in the Rules. The question is put not in terms of 'knowing' but of 'appreciating'. This means being able to think rationally about, and consider with some composure and reason, the wrongfulness of the act. It is therefore a means of taking into account the affective state of the accused and its interaction with the cognitive processes, or their emotional concomitants, thus meeting the criticism that the Rules ignore the affective disturbances that occur in mental disorder.

This meaning of 'know' is now also codified in several Australian jurisdictions: the Commonwealth, the Australian Capital Territory, the Northern Territory and Victoria. For example, in Victoria, the Crimes (Mental Impairment and Unfitness to be Tried) Act 1997 refers to the ability to 'reason with a moderate degree of sense and composure about whether the conduct [...] was wrong'.

In Queensland, Western Australia and Tasmania, where the criminal codes are based on the Griffith Code, the knowledge requirement calls for a capacity-based interpretation. In Queensland (Criminal Code (Qld): section 27(1)) and Western Australia (Criminal Code (WA): section 27) it has to be demonstrated that the accused lacked the 'capacity to know' that they 'ought not to do the act or make the omission' and in Tasmania (Criminal Code (Tas): section 16(1)) the test is being 'incapable of knowing that the act or omission was one that he or she ought not to do or make'.

\section{New Zealand}

In New Zealand the wrongfulness test has been codified in the Crimes Act 1961 (chapter 23(2)(b)): 'incapable of knowing that the act or omission was morally wrong, having regard to the commonly accepted standards of right and wrong'. This appears to be a normative test, but in practice it is interpreted as a subjective test, 'the question being whether the accused did not regard the act as wrong for him or her to do, even if he or she knew it was contrary to public standards of morality' (Yannoulidis 2012).

\section{Canada}

In 1990 the Supreme Court of Canada not only rejected Windle, but also ruled on the meaning of what it is to 'know' that an act is wrong (Box 5). This has been recognised as an important judgment as it 'reflects more accurately the true nature of the distorted thought processes of those whose psychiatric disorders impact on their capacity to know right from wrong' (Mackay 2009).

\section{Northern Ireland}

In Northern Ireland there is a statutory definition of insanity (Box 6).

\section{Jersey}

Jersey has abandoned the Rules in favour of what is explicitly a criminal responsibility defence (Box 7)

\section{BOX 5 Key Canadian judgments}

$R v$ Chaulk [1990]: "The word "wrong" [...] should be interpreted to mean "morally" and not "legally wrong" [...]. [T]he courts must determine whether the accused, because of disease of the mind, was rendered incapable of knowing that the act committed was something that he ought not to have done. To do so, the inquiry cannot terminate with the discovery that the accused knew that the act was contrary to the formal law. A person may well be aware that an act is contrary to law but [...] is at the same time incapable of knowing that it is morally wrong according to the moral standards of society.'

$R v$ Oommen [1994]: '[T]he inquiry focuses not on general capacity to know right from wrong, but rather on the ability to know that a particular act was wrong in the circumstances. The accused must possess the intellectual ability to know right from wrong in an abstract sense. But he or she must also possess the ability to apply that knowledge in a rational way to the alleged criminal act. [...] [T] he real question is whether the accused should be exempted from criminal responsibility because a mental disorder at the time deprived him of the capacity for rational perception and hence rational choice about the rightness or wrongness of the act.' 


\section{B0X 6 Statute law in Northern Ireland}

"In this Act [...] "insane person" means a person who suffers from mental abnormality which prevents him:

(a) from appreciating what he is doing

(b) from appreciating that what he is doing is either wrong or contrary to the law; or

(c) from controlling his own conduct; and

"insanity" shall be construed accordingly.'

(Criminal Justice Act (Northern Ireland) 1966: section 1 )

and one suggested by Professor R. D. Mackay, who is the leading authority on the insanity defence.

\section{Scotland}

Scotland has also put the law of insanity on a statutory basis. Under section 168(1) of the Criminal Justice and Licensing (Scotland) Act 2010 it is a defence if the accused is "unable by reason of mental disorder to appreciate the nature or wrongfulness of the conduct'. In the explanatory notes, 'appreciate' is interpreted as meaning that the accused 'knew that his conduct was in breach of legal or moral norms but [...] had reasons for believing that he was nevertheless right to do what he did'.

\section{Catching up?}

As long ago as 1874 Sir James Stephen attempted unsuccessfully to reform the law of insanity with his Homicide Amendment Bill. After more than another century of inconsequential recommendations for reform it is understandable that the outcome of the Law Commission's recent proposals for the reform of the insanity defence in England and Wales (Law Commission 2013) (Box 8) should be awaited with bated breath. They are important proposals not least because the Commission implicitly rejects Codère by asserting that 'Appreciation of the nature of an act surely includes appreciation of its moral qualities' (Law Commission 2013: p. 57). However, in my opinion, there are weaknesses in the proposed reforms (Rix 2015).

BOX 7 The law on insanity in Jersey

' $[A]$ person is insane [...] if at the time of the commission of the offence, his unsoundness of mind affected his criminal behaviour to such a substantial degree that the jury consider that he ought not to be found criminally responsible."

(A-G v Prior [2001])
B0X 8 The Law Commission's proposals for reform of the defence of insanity

The proposal is that the present insanity defence will be replaced by a defence of 'not criminally responsible by reason of a recognised medical condition'. This will go with a requirement that there must be expert evidence to the effect that:

'the defendant wholly lacked the capacity:

(i) rationally to form a judgment about the relevant conduct or circumstances;

(ii) to understand the wrongfulness of what he or she is charged with having done; or

(iii) to control his or her physical acts in relation to the relevant conduct or circumstances

as a result of a qualifying recognised medical condition.'

(Law Commission 2013: p. 20)

In the context of this article, the most important weakness is that 'wrongfulness' is not qualified in the proposed defence. The Law Commission has accepted that, contrary to Codère, the nature of an act includes an appreciation of its moral qualities, but without making this explicit, there is a risk that Windle might again rule the day. The remedy is to insert the words 'moral or legal' before the word 'wrongfulness'.

What is also missing from the defence is a reference to 'composure' or 'calmness' and this needs to be included to allow sufficiently for the affective component in mental disorders. This could be remedied by inserting, after 'capacity', the words 'with composure or calmness' or, following Mr Justice Stephen in Davis, 'with a moderate degree of composure or calmness' or, following Porter, 'some degree of composure or calmness'.

A further criticism of the proposed defence is the requirement of a total lack of capacity, which elsewhere has been described as a mistake (Stanton-Ife 2015). As illustrated below, this will restrict the use of the defence and may indeed make it as restrictive as the Rules are when strictly applied. Although the Commission justifies this qualification on the basis that the defence is not a defence of diminished responsibility but one of no responsibility (Law Commission 2013: p. 46), no other jurisdiction has introduced this requirement. Taking the example of Jersey, the remedy would be to replace 'wholly' with 'substantially'.

As recognised by the Law Commission (2013: p. 56), if 'wrongfulness' is to be interpreted as meaning 'morally wrong', this begs the question of whose morality is to be regarded as the standard by which the accused's appreciation is judged. On the one hand it would be undesirable for the court 
to conduct an inquiry into what was generally regarded as morally wrong, but on the other hand the standard cannot be wholly subjective to the accused. However, incorporation of the Australian reference to what 'a body of reasonable men understand [to be] right [or] wrong' ( $R$ v Porter (1933), or the New Zealand reference to 'public standards of morality' (Yannoulidis 2012), would allow the reasonable men and women of the jury to be the judges of the applicable standard.

\section{Three illustrative cases}

The following three cases from my own practice illustrate the difficulties in applying the current law of insanity in England and Wales.

Box 9 outlines the case of a man with bipolar disorder who suffered a manic episode and was charged with the attempted murder of a fellow patient. There was evidence that a lot of the time he was aware of what he was doing and he admitted an intention to kill. However, there was uncertainty as to whether he knew that what he was doing was wrong. At its strongest, his case was that, as he said not long after, 'it felt right at

\section{B0X 9 Successful defence of insanity in a case of attempted murder}

This 31-year-old man had had a bipolar illness since he was about 20. He had a positive family history of psychiatric disorder.

He experienced a further episode of illness with grandiose delusions about being or becoming a doctor, an unjustified belief of financial wealth, a belief that he did not have to pay for things, overactivity, polydipsia, disinhibition, over-talkativeness, rhyming associations, insomnia, overfamiliarity, persecutory ideas and command hallucinations.

In the course of this illness, following a collapse and urinary incontinence, and with a history of fainting spells and nausea, he was admitted to a medical ward for neurological and related investigations. That evening he was restless and agitated. His behaviour was strange and he made several attempts to leave the ward in the early hours of the morning 'as he had a party to arrange'. He began interfering with other patients' records and said that he needed to write his report. At $04.00 \mathrm{~h}$ he entered another patient's room and initially prevented staff entering. When they did, referring to himself in the third person, he said that he was dead. He had a glazed and vacant look in his eyes. He then pushed the patient's mask into her face and began to strangle her with her oxygen tubing After collapsing on the patient's bed, he was removed from the room but became aggressive. After long periods of silence with occasional mumblings of 'dancer, bouncer, marijuana, nan' he said that he had 'wanted to kill the patient to protect his family'. He later told one psychiatrist that he had been hearing voices and people had been telling him to do things and he told another that he had 'tried to strangle someone because I wanted to get back to reality' and 'it felt right at the time'. In his interview with the police he said, 'The reason why I did this was that I had been denied the spirits and to get back to this I'd have to kill a person but I'm not usually like this'.

When examined for trial purposes he said that he thought that he would not see his wife and daughter again so 'the only way back was to take another life', but 'we were all one and if anything it was me I was killing'. Attempts were made to ascertain whether he had thought that it was wrong to kill and eventually he said, 'I wasn't thinking of many rational decisions. I don't know if I thought that it was wrong to kill'. the time'. He was fortunate that his plea of insanity was accepted, given the lack of sufficiently clear evidence that he did not know that what he was doing was wrong. However, it would probably have been accepted in a number of other jurisdictions. Under the proposed Law Commission reforms, however, although he could not rationally form a judgement about his conduct or understand its wrongfulness, there could well be argument as to whether or not he wholly lacked capacity in these respects.

The second case is that of a man, whose first name was Leo, who believed that he was 'Leo the Lion of Judah', that he was second only to God and that God's law required him to kill his neighbour for refusing him access to his telephone so that he could claim the keys to Jerusalem (Rix 2011). He knew that killing his neighbour was against the law of the land. Notwithstanding that on a Windle interpretation of the Rules, he knew that he was doing what was wrong, his defence of insanity went unchallenged and he was found not guilty by reason of insanity. On a strict application of Windle, in order to succeed, he would have needed an additional delusional belief that the law of the land as to homicide was wrong, had been repealed or had been superseded by the law to which he believed that he was subject. In terms of the law of the land, he did understand the wrongfulness of that with which he was charged. Under the reforms proposed by the Law Commission, what is uncertain is whether or not he would be found to have wholly lacked the capacity to form a judgement about his conduct or circumstances.

Box 10 cites the case of organic psychosis resulting from hypothyroidism (Nathan 1997). I did not support an insanity defence because it would not have been possible to persuade a jury that the accused did not know that killing his wife was wrong. However, as in the case of Johnson, 'It appears that the appellant in this case may have been unfortunate to have had legal and medical practitioners who applied the strict letter of the law' (Ormerod 2008) or unfortunate not to have had an expert who, to paraphrase Mackay, made little attempt to distinguish between lack of knowledge of legal and moral wrongness (Mackay 1990). In other jurisdictions an insanity defence could, and probably would, have been supported.

\section{The way forward}

If psychiatrists apply the strict letter of the law as established and confirmed in Windle, the defence of insanity in England and Wales will remain beyond the reach of a multitude of mentally disordered people who would not otherwise be 
criminalised. The continued success of a liberal and relaxed approach to the defence, dependent on psychiatrists who are ignorant of the law or bending it, may benefit the majority. But this will be at the price of failure in the cases of those who do not persuade the medical experts or courts that they have a valid defence of insanity having regard to the effect of Windle.

What is needed in England and Wales is a large number of unsuccessful insanity cases, covering a range of diagnoses, in which the trial judges have refused to allow the issue to be put to the jury on the strict application of Windle or where the jury has been so directed (Rix 2015). These cases then need to go to the Supreme Court, where the Court may be persuaded to interpret the Rules as courts of first instance have done for nearly 200 years in England and Wales and as neighbouring jurisdictions have done by the development of their common law or statutory reform.

Box 11 sets out the questions that I suggest should be addressed in a case where the defence of insanity is raised. They draw on the interpretation of the insanity defence in the courts of first instance in England and Wales, its interpretation in courts of first instance and appellate courts in other jurisdictions and the statutory reforms of the insanity law in other jurisdictions. I use the terms 'competent understanding' and 'appreciation' instead of 'know'. This is in the sense of being able to think rationally of all the different reasons that have a bearing on the rightness or wrongness of an action, to think calmly and rationally or with some, or a moderate, degree of calmness, sense or composure of the action's wrongness or to have the capacity to know the wrongfulness of the act. It is also in the sense of 'appreciating' that, albeit the conduct was in breach of legal or moral norms, there were reasons for believing that the action was right.

These questions deliberately go beyond the questions that arise from a strict interpretation of the law of insanity, thus inviting the Court of Appeal or the Supreme Court, in appropriate cases, to allow appeals on the basis of what, I submit, is the true meaning of wrongfulness in the Rules, or alternatively, but I hope and expect not, to reject such grounds of appeal and justify the strict position adopted in Windle.

\section{Conclusions}

The insanity defence in England and Wales is unsatisfactory. Its successful application depends on a disregard for the Court of Appeal's interpretation of the M'Naghten Rules. It relies on psychiatrists who are clumsy, woolly, superficial,

\section{BOX 10 An unsuccessful insanity defence}

A hitherto happily married man, who was being treated with thyroxine for hypothyroidism, became increasingly suspicious over several weeks. He believed that others were watching him and checking up on his movements. During the night before the offence, he woke his wife several times expressing his conviction that his medication had been tampered with and accusing her of trying to poison him. He believed that everything was monitored by the Department of Social Security and that his wife was a party to the surveillance. He said that people had been whispering and talking about him. The next day he stabbed his wife, attempted to strangle her and punched her. When arrested, he said I'm going to die. Tomorrow I'm going out of the country. 'Cos I'm immigrant they're going to inject me. Because I'm going to die I wanted my wife to be in heaven with me. I've stabbed her because I wanted her to be there when I get there'.

When interviewed by the police, he admitted stabbing his wife with the intention of killing her. Expert medical opinion was in agreement to the effect that he had become psychotic as a result of a failure to adhere to his thyroxine therapy. His psychosis resolved with thyroxine treatment.

(Nathan 1997)

or ignorant of, or prepared to bend, the law, and lawyers who are prepared to be relaxed, liberal, creative or generous in its interpretation. Until there is statutory reform or the Supreme Court sets aside Windle, the observation of Lord Coleridge in 1888 (Robinson 1947: p. 33) will remain valid: 'The law in the matter of insanity is not incapable of being so interpreted as to do terrible injustice'.

\section{Acknowledegment}

I am grateful to Professor Nigel Eastman: following a lecture I gave on this subject he commented that in one case he had deliberately expressed his opinion in terms of 'appreciation' instead of 'knowledge' in the hope that it would lead to judicial discussion BOX 11 Questions to be answered in a case
where the insanity defence is raised

-Is there evidence of a defect of reasoning?

- Is there evidence of disease of the mind?

- Did the defect of reasoning arise from a disease of the mind?

- Did the accused have a competent understanding or appreciation of the nature of the act?

- Did the accused have a competent understanding or appreciation of the quality of the act?

- Did the accused know that the act is contrary to the law of the land?

- Did the accused have a competent understanding or appreciation of whether the act was wrong, having regard to the commonly accepted standards of right and wrong or according to the moral standards of society?

- Did the accused act with calmness or composure and, if not, to what degree was this lacking?
MCO answers

1 e 2 e 3 b $4 d \quad 5$ e 
as to the ambit of the defence. This prompted me to extend the scope of this article to deal with the knowledge as well as the wrongfulness element of the Rules. I am particularly grateful to my former patient (the subject of Box 9) for permission to include details of his case which, unlike the details in the other two cases, are not in the public domain.

\section{References}

Benson AC, Esher, Viscount (eds) (1908) The Letters of Queen Victoria: vol. 1 - 1837-1843. John Murray.

Diamond BL (1977) On the spelling of Daniel M'Naghten's name. In Daniel McNaughton: His Trial and the Aftermath (eds DJ West, A Walk): 86-90. Gaskell Books.

Hansard (1843a) Parl Debs (series 3), vol 67, cols 288-290 (6 Mar 1843).

Hansard (1843b) Parl Debs (series 3), vol 67, cols 714-744 (13 Mar 1843).

Justus (1843) On a late acquittal. The Times (London): 6 March.

Law Commission (2013) Criminal Liability: Insanity and Automatism: A Discussion Paper. Law Commission.

Mackay RD (1990) Fact and fiction about the insanity defence. Criminal Law Review, 247-55.

Mackay RD, Kearns G (1999) More facts about the insanity defence. Criminal Law Review, 714-25.

Mackay RD, Mitchell BJ, Howe L (2006) Yet more facts about the insanity defence. Criminal Law Review, 399-411.

Mackay RD (2009) Righting the wrong? Some observations on the second limb of the M'Naghten Rules. Criminal Law Review, 80-9.

Moran R (1981) Knowing Right from Wrong: The Insanity Defense of Daniel McNaughtan. Free Press.

Nathan T, Rix KJB, Kent JH (1997) Myxoedematous madness and grievous bodily harm. Journal of Clinical Forensic Medicine, 4: 85-90.
Ormerod D (2008) Insanity: knowledge of right and wrong - 'wrong' meaning against the law. Criminal Law Review, 132.

Rix KJB (2011) Expert Psychiatric Evidence. RCPsych Publications.

Rix KJB (2015) Prizing open the door to justice: reforming the 'wrongfulness limb' of the M'Naghten Rules. In Mental Condition Defences and the Criminal Justice System: Perspectives from Law and Medicine (eds N Wake, A Reed, B Livings): 105-29. Cambridge Scholars.

Robinson E (1947) Just Murder. Lincolns Prager.

Stanton-Ife J (2015) Total incapacity. In Mental Condition Defences and the Criminal Justice System: Perspectives from Law and Medicine (eds N Wake, A Reed, B Livings): 130-58. Cambridge Scholars.

Stephen JF (1883) History of the Criminal Law of England (vol 2). Macmillan.

Yannoulidis S (2012) Mental State Defences in Criminal Law. Ashgate.

\section{Cases}

A-G v Prior [2001] JLR 146.

M'Naghten's Case (1843) 10 Cl \& Fin 210.

$R$ v Chaulk [1990] 3 SCR 1303.

$R$ v Codère (1917) 12 Cr App R 21.

$R v$ Davis (1881) 14 Cox CC 563.

$R$ v Higginson (1843) 1 Car \& K 129.

$R v$ Johnson [2007] EWCA Crim 1978.

$R$ v Oommen [1994] 2 SCR 507.

$R$ v Porter (1933) 55 CLR 182.

$R v$ Sodeman [1936] HCA 75.

$R$ v True (1922) 16 Cr App R 164.

$R v$ Vaughan (1844) 1 Cox CC 80

$R v$ Windle [1952] 2 OB 826.

Stapleton v $R$ (1952) 86 CLR 358.

\section{MCQs}

Select the single best option for each question stem

1 Daniel McNaughtan's trial in 1843:

a resulted in his conviction for the wilful murder of Edward Drummond, private secretary to the prime minister

b lasted from 4 March to 19 June

c reassured the public as to their protection from dangerous lunatics

$d$ resulted in a verdict of guilty but insane

$\mathrm{e}$ included a direction to the jury in terms of 'competent use of his understanding'.

\section{The M'Naghten Rules:}

a came about when the House of Lords adopted a unique approach to the clarification of the law by the judges of the Court of Common Pleas

$b$ are based on the unanimous views of the judges of the Court of Common Pleas

c no longer represent the law on insanity in England and Wales

d state that if the accused was conscious that the act was one that he ought not to do, or if that act was at the same time contrary to the law of the land, he is punishable

e state that to establish a defence on the ground of insanity it must be clearly proved that, at the time of committing the act, the party accused was labouring under a defect of reason from disease of the mind.

\section{According to the Court of Appeal of} England and Wales:

a the moral aspects of the alleged act are what is meant in the Rules by the 'quality of the act'

b the word 'wrong' in the Rules means contrary to law

c it is important to explore the distinction between moral and legal wrongness

$d$ the term 'nature and quality of the act' refers to the distinction between the physical and moral aspects of the act

e it should be left to juries to consider whether the act was morally right or wrong.

\section{Empirical research into the operation of} the insanity defence in England and Wales has shown that:

a psychiatrists usually make a clear distinction between lack of knowledge of legal and moral wrongfulness

b psychiatrists generally deal with the wrongfulness issue according to the strict interpretation of the Rules by the Court of Appeal c psychiatrists almost always make clear on which limb, the 'nature and quality' limb or the 'wrongfulness' limb, they are relying

$d$ the wrongfulness issue is generally treated in a liberal fashion

e psychiatrists bend the law.

5 In a psychiatric report in a case in which the defence of insanity is raised:

a the opinion should be framed having regard only to the Court of Appeal's interpretation of the law of insanity

b there is no need to attempt to distinguish between lack of knowledge of legal and moral wrongfulness

c lack of intent attributable to mental illness or psychosis can be used as the basis for supporting a defence of insanity according to the M'Naghten Rules

d clumsy, woolly and superficial reasoning does not matter because it is possible to rely on the lawyers to interpret the law of insanity in a liberal, creative or generous way

e it is appropriate to take into account the accused's degree of calmness or composure at the material time. 